\title{
Pengembangan Model Pembelajaran Interaktif Berbasis Think Pair Share untuk Meningkatkan Kemampuan Komunikasi Matematis Siswa
}

\author{
Siti Asfiranna Sari Dalimunthe ${ }^{1}$, Mulyono², Edi Syahputra ${ }^{3}$ \\ 1, 2,3, Prodi Pendidikan Matematika Pascasarjana, Universitas Negeri Medan \\ ${ }^{1}$ Universitas Negeri Medan, Jalan William IskandarPasar V, Medan, Indonesia \\ siti.asfiranna@gmail.com
}

\begin{abstract}
This study aims to: 1) determine the development of an interactive learning model based on think pair share on material (square and rectangle) that is valid, practical, and effective so that it can improve students' mathematical communication skills; and 2) describe the improvement of mathematical communication skills using an interactive learning model based on think pair share. This research is development research. The development model used in this research is the ADDIE model. The results showed that: 1) the development of an interactive learning model based on think-paur share that was developed met the criteria of validity, practicality, and effectiveness; and 2) the increase in mathematical communication skills using an interactive learning model based on think pair share increased in terms of the N-gain trial I of 0.30 with low criteria and in the second trial with moderate criteria.
\end{abstract}

Keywords: Interactive Learning Model, Think Pair Share, Mathematical Communication

\begin{abstract}
Abstrak
Penelitian ini bertujuan untuk: 1) mengetahui pengembangan model pembelajaran interaktif berbasis think pair share pada materi bangun datar (persegi dan persegi panjang) yang valid, praktis, dan efektif sehingga dapat meningkatkan kemampuan komunikasi matematis siswa; dan 2) mendeskripsikan peningkatan kemampuan komunikasi matematis mengunakan model pembelajaran interaktif berbasis think pair share. Penelitian ini merupakan penelitian pengembangan. Model pengembangan yang digunakan dalam penelitian ini adalah model ADDIE. Hasil penelitian menunjukkan bahwa: 1) pengembangan model pembelajaran interajktif berbasis think paur share yang dikembangkan memenuhi kriteria kevalidan, kepraktisan dan keefektifan; dan 2) peningkatan kemampuan komunikasi matematis mengunakan model pembelajaran interaktif berbasis think pair share meningkat ditinjau dari Ngain uji coba I sebesar 0,30 dengan kritera rendah dan pada uji coba II dengan kriteria sedang.
\end{abstract}

Kata kunci: Model Pembelajaran Interaktif, Think Pair Share, Komunikasi Matematis

Copyright (c) 2022 Siti Asfiranna Sari Dalimunthe, Mulyono, Edi Syahputra

$\triangle$ Corresponding author: Siti Asfiranna Sari Dalimunthe

Email Address: siti.asfiranna@gmail.com (Jalan William IskandarPasar V, Medan, Indonesia)

Received 22 January 2022, Accepted 05 February 2022, Published 07 February 2022

\section{PENDAHULUAN}

Menurut (Tampubolon \& Syahputra, 2017) menyatakan bahwa model pembelajaran adalah rangkaian dari pendekatan, strategi, metode, teknik, dan taktik pembelajaran. Model pembelajaran pada dasarnya merupakan bentuk pembelajaran yang tergambar dari awal sampai akhir yang disajikan secara khas oleh guru. Dengan kata lain, model pembelajaran merupakan bungkus atau bingkai dari penerapan suatu pendekatan, strategi, metode dan teknik pembelajaran. Widayati (Widayati, 2012) menyatakan bahwa kualitas dan keberhasilan pembelajaran sangat dipengaruhi oleh kemampuan dan ketepatan guru dalam memilih dan menggunakan model pembelajaran.

Pengembangan model pembelajaran sangat dibutuhkan karena akan berdampak positif terhadap kemampuan dan keaktifan siswa dalam belajar ('Ainin et al., 2020). Hal ini disebabkan karena model pembelajaan merupakan salah satu komponen yang dapat mempengaruhi pencapaian 
tujuan pembelajaran (Rahmawati \& Suryanto, 2014). Tidak jauh berbeda Abidin, Mohamed, dan Ghani (Abidin, 2016) menjelaskan bahwa pengembangan model pembelajaran dapat mendorong siswa dalam pemerolehan dan pemahaman materi pelajaran. Kemudian Wibowo, Budiyono dan Subanti (Wibowo et al., 2014) menjelaskan bahwa pengembangan model pembelajaran diperlukan untuk membuat siswa berperan lebih aktif dalam pembelajaran.

Namun kenyataan berbanding terbalik dengan teori yang ada. Dalam proses pembelajaran guru hanya menerangkan materi pelajaran saja yaitu masih mengembangkan model pembelajaran yang berpusat pada guru yaitu model pembelajaran konvensional. Akibatnya siswa sering mengantuk saat proses pembelajaran, berbicara sendiri dan melakukan aktivitas lain selama proses pembelajaran. Di kelas X Teknik Gambar Bangunan yakni mengalami masalah kurangnya keberanian siswa untuk mengungkapkan kesulitan yang dialaminya kepada guru dalam memahami materi yang diajarkan sehingga siswa bersifat pasif dalam proses pembelajaran. Masalah lain yang terjadi yaitu kurangnya kemampuan pemahaman siswa dalam proses pembelajaran (Iswari, 2018). Karena pemilihan guru menerapkan model pembelajaran konvensional yang dirasa masih kurang sesuai jika ditinjau dari mata pelajaran dan keadaan di kelas, yang kemudian berpengaruh pada hasil belajar siswa. Seperti yang dijelaskan oleh Abidin, Mohamed, dan Ghani (2016) bahwa sewaktu melaksanakan aktivitas pembelajaran guru menggunakan model pembelajaran yang tidak sesuai dengan materi yang diajarkan. Mayoritas guru menggunakan model konvensional dalam melaksanakan aktivitas pembelajaran, model pembelajaran yang mengedapankan guru sebagai sumber utama informasi. Dimana model pembelajaran kovensional ini adalah model pembelajaran yang bersifat satu arah dan guru hanya menjelaskaan tanpa ada interaksi dari siswa. Model pembelajaran yang dijalankan guru dalam proses pembelajaran sekarang ini kurang memperhatikan keterlibatan siswa secara aktif. Wibowo, Budiyono dan Subanti (Wibowo et al., 2014) menjelaskan bahwa model pembelajaran yang diterapkan oleh guru disekolah masih kurang medorong siswa untuk mengembangkan kemampuan berpikir.

Model pembelajaran matematika saat ini belum mengacu pada teori pembelajaran yang spesifik. Pada proses pembelajaran di dalam kelas, siswa diberikan permasalahan rutin yang dapat diselesaikan dengan analisis sederhana dan penyelesaian yang mekanistik. Hampir semua proses pembelajaran matematika diawali dengan pemberian pengertian, rumus, contoh, dan diakhiri dengan latihan-latihan. Sesekali ditemukan pembuktian masalah-masalah matematika yang diselesaikan dengan menggunakan gambar atau sketsa sederhana (Syahputra \& Surya, 2015).

Salah satu kemampuan matematis yang menjadi tujuan pembelajaran matematika adalah kemampuan komunikasi matematis. Menurut Mahmuzah, Ikhsan dan Yusrizal (Mahmuzah et al., 2014) kemampuan komunikasi matematis adalah kemampuan komunikasi dalam pembelajaran yang sangat penting untuk dikuasai siswa, karena untuk menyelesaikan siswa memerlukan komunikasi, baik itu berupa komunikasi dalam bentuk lisan atau pun tulisan. 
Kemampuan Komunikasi matematis sangat penting di dalam pembelajaran matematika karena melalui komunikasi peserta didik dapat mengorganisasikan dan mengkonsolodasi berpikir matematisnya, serta peserta didik dapat mengexplore ide-ide matematika. Kesadaran tentang pentingnya memperhatikan kemampuan peserta didik dalam berkomunikasi dengan menggunakan matematika yang dipelajari di sekolah perlu ditumbuhkan, karena salah satu fungsi pelajaran matematika adalah sebagai cara mengkomunikasikan gagasan secara praktis, sistematis, dan efisien (Jurotun, 2015).

Hal tersebutlah yang juga terjadi di MTS Amin Darussalam Bandar Setia, dalam proses pembelajaran matematika guru belum pernah membuat pembaharuan pada model pembelajaran, guru biasanya hanya menggunakan model pembelajaran konvensional atau selama proses pembelajaran guru hanya membentuk siswaa dalam beberapa kelompok kecil, kemudian menjelaskan permasalahan, memberikan contoh soal, kemudian diakhiri dengan pemberian latihan-latihan. Tentu saja model pembelajaran yang seperti itu tidak menuntut siswa menjadi aktif dalam proses pembelajarannya, siswa hanya duduk dan mendengarkan penjelasan dari guru. Tentu saja hal ini akan berdampak negatif terhadap kemampuan komunikasi matematis siswa. Dari hasil observasi awal yang penulis temukan di MTS Amin Darussalam, bahwa kemampuan komunikasi matematis siswa masih dikategorikan rendah. Hal ini terlihat dari jawaban siswa tentang suatu soal yang mengukur kemampuan komunikasi matematis, dengan karakteristik soal yaitu meminta siswa untuk menjelaskan prosedur penyelesaian terhadap soal cerita yang diberikan.

Salah satu model pembelajaran yang dapat dikembangkan adalah model pembelajaran Think Pair Share. Pembelajaran Think Pair Share merupakan model pembelajaran yang memberikan lebih banyak kesempatan kepada siswa untuk belajar secara mandiri dan berpasangan dalam merespon pembelajaran, sehingga siswa dapat terlibat aktif dalam pembelajaran di kelas . Adanya tahapan dalam pembelajaran Think Pair Share seperti Think (berpikir), Pairing (berpasangan) dan Sharing (berbagi) (Perwitosari et al., 2018). Model ini dianggap mampu untuk meningkatkan kemampuan komunikasi matematis siswa.

Model pembelajaran Think Pair Share memberikan kesempatan pada siswa untuk lebih leluasa dalam berpikir dan merespon pengetahuan maupun soal yang diberikan. Siswa diberi kesempatan untuk berdiskusi dan mengembangkan pengetahuan bersama dengan pasangannya sehingga siswa mampu meningkatkan kemampuannya (Aminudin, 2017). Selain itu model pembelajaran Think Pair Share, memberikan kesempatan kepada siswa untuk bekerja sendiri serta bekerja sama deng an orang lain baik itu teman sebangkunya, maupun teman sekelasnya. Model ini lebih mengutamakan aktifitas siswa dalam proses pembelajaran dan memberi siswa lebih banyak waktu untuk berfikir, merespon dan saling membantu, tidak membutuhkan waktu yang lama untuk membentuk kelompok, dan guru dapat dengan mudah memantau aktifitas siswanya (Rahayu \& Wirevenska, 2019).

Berdasarkan pengamatan peneliti, rendahnya kemampuan komunikasi matematis berhubungan dengan pembelajaran matematika yang dirancang oleh guru. Untuk menyikapi permasalahan di atas, 
guru dituntut mampu mencari dan menemukan suatu cara yang mampu mengoptimalkan kemampuan komunikasi matematis siswa. Komunikasi matematika berperan untuk memahami ide-ide matematika secara benar. Siswa yang memiliki kemampuan komunikasi matematika yang lebih memudahkan dalam mendapatkan alternatif-alternatif penyelesaian berbagai permasalahan matematika. Diharapkan melalui penelitian pengembangan perangkat pembelajaran digital ini dapat menjadi alternatif untuk mewujudkan proses pembelajaran yang berkualitas dan juga diharapkan dapat meningkatkan kemampuan komunikasi matematis siswa.

\section{METODE}

Penelitian ini adalah penelitian pengembangan (development research) yang menggunakan model pengembangan ADDIE yaitu tahap analysis (analisis), design (perancangan), development (pengembangan), Implementation (penerapan) dan evaluation (evaluasi). Penelitian pengembangan ini bertujuan mengembangkan model pembelajaran untuk meningkatkan kemampuan komunikasi matematis dalam pembelajaran di kelas. Penelitian ini dilaksanakan di MTS Amin Darussalam Bandar Setia. Waktu penelitian ini dilakukan pada semester ganjil tahun pelajaran 2020/2021. Subjek dalam penelitian ini adalah siswa kelas VII MTS Amin Darussalam Bandar Setia tahun ajaran 2020/2021. Sedangkan objek dalam penelitian ini untuk mengukur kualitas model pembelajaran dalam meningkatkan kemampuan komunikasi dan Self-Efficacy serta perangkat yang digunakan dalam pembelajaran adalah Buku Siswa (BS), Lembar Kerja Peserta Didik (LKPD), tes kemampuan komunikasi matematis dan angket self-efficacy.

Dalam pengembangan model pembelajaran interaktif ini menggunakan model pengembangan ADDIE (Analysis, Design, Development, Implementation, and Evaluation). Model ini bersifat relatif lebih praktis dan dapat diukur secara bertahap atau sistematis dan dapat digunakan untuk mendesain dan mengembangkan aktivitas pembelajaran. Berikut penjelasan dari tahap pengembangan ADDIE yang akan peneliti lakukan:

\begin{tabular}{|c|l|}
\hline $\begin{array}{l}\text { Analisis kebutuhan siswa, karakteristik siswa, kurikulum dan tujuan } \\
\text { pembelajaran untuk menentukan masalah serta solusi yang sesuai }\end{array}$ \\
Analysis \\
Development
\end{tabular}


Lembar validasi instrumen pembelajaran digunakan untuk memperoleh data tentang kualitas perangkat pembelajaran berdasarkan penilaian para ahli (validator). Lembar validasi untuk Rencana Pelaksanaan Pembelajaran (RPP), Buku Siswa, Lembar Kerja Peserta Didik (LKPD), lembar validasi tes kemampuan komunikasi matematis dan angket self-efficacy siswa. Lembar validasi ini berisikan komponen - komponen yang dinilai antara lain: format, ilustrasi bahasa dan isi. Selanjutnya, bentuk instrumen tes kemampuan komunikasi matematis adalah tes uraian, dengan kisi - kisi dan penskoran tes sebagai berikut:

Tabel 1. Kisi - Kisi Tes Kemampuan Komunikasi Matematis

\begin{tabular}{|c|c|}
\hline Indikator Komunikasi Matematis & Materi \\
\hline $\begin{array}{l}\text { Menyatakan permasalahan kehidupan sehari-hari } \\
\text { kedalam model atau bahasa matematika }\end{array}$ & \multirow{3}{*}{ SegiEmpat } \\
\hline $\begin{array}{l}\text { Menginterpretasikan gambar kedalam simbol atau } \\
\text { bahasa matematika. }\end{array}$ & \\
\hline $\begin{array}{l}\text { Menuliskan informasi dari pernyataan kedalam } \\
\text { model atau bahasa matematika. }\end{array}$ & \\
\hline
\end{tabular}

Setelah pembuatan kisi-kisi, dilanjutkan dengan menyusun soal beserta kunci jawaban dan aturan pemberian skor tiap butir soal. Untuk memberikan skor terhadap jawaban hasil tes, berikut adalah pedoman penskoran untuk aspek kemampuan komunikasi matematis.

Tabel 2. Pedoman Penskoran Tes Kemampuan Komunikasi Matematis

\begin{tabular}{|c|c|c|}
\hline Aspek Komunikasi & Indikator & Skor \\
\hline \multirow[t]{5}{*}{$\begin{array}{l}\text { Menyatakan permasalahan } \\
\text { kehidupan sehari-hari kedalam } \\
\text { model atau bahasa matematika }\end{array}$} & $\begin{array}{l}\text { Dapat menyatakan masalah sehari-hari kedalam } \\
\text { simbol atau bahasa matematis dengan lengkap } \\
\text { dan benar. }\end{array}$ & 4 \\
\hline & $\begin{array}{l}\text { Dapat menyatakan hamper semua masalah sehari- } \\
\text { hari kedalam simbol atau bahasa matematis } \\
\text { denganbenar. }\end{array}$ & 3 \\
\hline & $\begin{array}{l}>\text { Hanya sebagian kecil masalah sehari-hari } \\
\text { kedalam simbol atau bahasa matematis. }\end{array}$ & 2 \\
\hline & $\begin{array}{l}\text { Tidak dapat menyatakan masalah sehari-hari } \\
\text { kedalam simbol matematis atau siswa menuliskan } \\
\text { jawaban tetapi tidak mengarah kepada jawaban } \\
\text { yang benar. }\end{array}$ & 1 \\
\hline & $>$ Tidak menjawab/ jawaban kosong. & 0 \\
\hline \multirow{5}{*}{$\begin{array}{l}\text { Menginterpretasikan gambar } \\
\text { kedalam symbol atau bahasa } \\
\text { matematika }\end{array}$} & $\begin{array}{l}\text { Menghubungkan gambar kedalam model } \\
\text { matematika dengan lengkap dan benar. }\end{array}$ & 4 \\
\hline & $\begin{array}{l}\text { Dapat menghubungkan hamper semua gambar } \\
\text { kedalam model matematika. }\end{array}$ & 3 \\
\hline & $\begin{array}{l}\text { Hanya sebagian kecil dapat menghubungkan } \\
\text { gambar kedalam model matematika. }\end{array}$ & 2 \\
\hline & $\begin{array}{l}\text { Menghubungkan gambar kedalam model } \\
\text { matematika tetapi tidak mengarah pada jawaban } \\
\text { yang benar atau salah. }\end{array}$ & 1 \\
\hline & $>$ Tidak menjawab. & 0 \\
\hline \multirow{2}{*}{$\begin{array}{l}\text { Menuliskan informasi dari } \\
\text { pernyataan kedalam model atau } \\
\text { bahasa matematika }\end{array}$} & $\begin{array}{l}\text { Menuliskan informasi dari pernyataan kedalam } \\
\text { bahasa matematika dengan lengkap dan benar. }\end{array}$ & 4 \\
\hline & $>$ Hampir menuliskan semua informasi dari & 3 \\
\hline
\end{tabular}




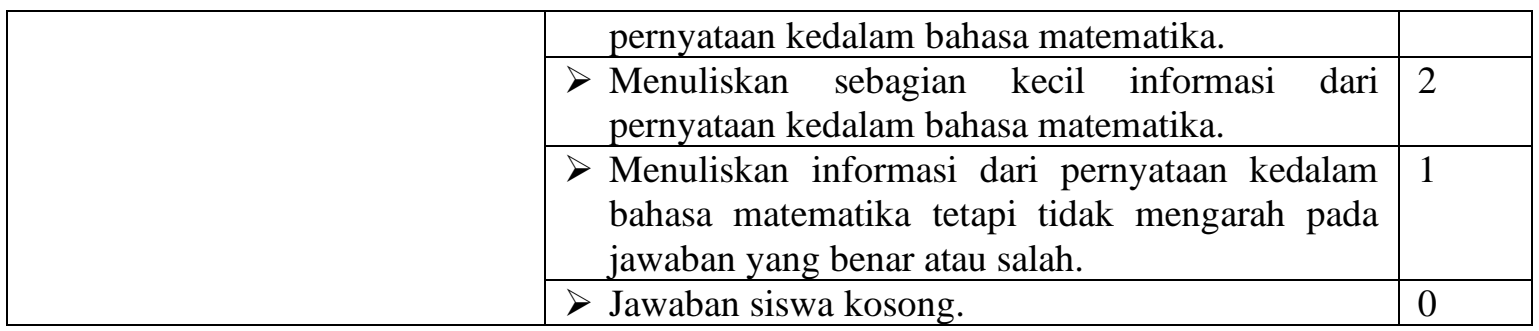

\section{Kepraktisan}

Kepraktisan Perangkat Pembelajaran diukur berdasarkan hasil penilaian pengamat untuk menyatakan dapat tidaknya perangkat dilaksanakan di kelas dengan menggunakan perangkat pembelajaran yang disediakan (Intended-Operational atau IO). Instrumen yang digunakan adalah lembar observasi keterlaksanaan perangkat pembelajaran yang telah dikembangkan. Kegiatan yang dilakukan untuk menganalisis data keterlaksanaan yang diperoleh dari hasil observasi adalah sebagai berikut:

1. Melakukan rekapitulasi data penilaian kevalidan perangkat penelitian ke dalam tabel yang meliputi: aspek (Ai), indikator (Ii), dan nilai (Pi).

2. Menentukan rata-rata nilai dari observer untuk setiap indikator dengan rumus (Susanto, 2012)

$$
I_{i}=\frac{\sum_{j=1}^{n} P_{j i}}{n}
$$

\section{Keterangan:}

$\mathrm{P}_{j i}$ adalah data nilai dari penilai ke-j terhadap indikator ke- $i$,

$n$ adalah banyaknya penilai (ahli dan praktisi)

3. Menentukan rata-rata nilai untuk setiap aspek dengan rumus:

$$
A_{i}=\frac{\sum_{j=1}^{m} I_{i j}}{m}
$$

(Susanto, 2012)

Keterangan:

$A_{i}$ adalah rerata nilai untuk aspek ke- $i$,

$\mathrm{I}_{i j}$ adalah rerata untuk aspek ke-i indikator ke-j,

$m$ adalah banyaknya indikator dalam aspek ke- $i$

4. Menentukan nilai Va atau nilai rata-rata nilai untuk semua aspek dengan rumus (Hobri, 2010):

$$
I O=\frac{\sum_{i=1}^{n} A_{i}}{n}
$$




\section{Keterangan:}

$I O$ adalah nilai rerata total untuk semua aspek

$A_{i}$ adalah rerata nilai untuk aspek ke- $i$,

$n$ adalah banyaknya aspek

Selanjutnya rerata nilai aspek (IO) ini dirujuk pada interval penentuan tingkat keterlaksanaan perangkat pembelajaran sebagai berikut:

Tabel 3. Interprestasi Tingkat Keterlaksanaan Perangkat Pembelajaran

\begin{tabular}{|l|l|}
\hline Interval Keterlaksanaan & Rerata Nilai Aspek \\
\hline $1 \leq \mathrm{IO}<2$ & Sangat rendah \\
\hline $2 \leq \mathrm{IO}<3$ & Rendah \\
\hline $3 \leq \mathrm{IO}<4$ & Sedang \\
\hline $4 \leq \mathrm{IO}<5$ & Tinggi \\
\hline $\mathrm{IO}=5$ & Sangat Tinggi \\
\hline
\end{tabular}

Sumber: (Hobri, 2010)

Kriteria menyatakan perangkat memiliki derajat IO yang baik adalah minimal tingkat IO yang dicapai adalah tinggi. Jika tingkat pencapaian IO yang dicapai adalah tinggi. Jika tingkat pencapaian IO dibawah tinggi, maka perlu dilakukan peninjauan dan revisi pada buku perangkat pembelajaran berdasarkan masukan (koreksi) para pengamat. Selanjutnya dilakukan uji coba. Uji coba ini dapat dilakukan berungkali sampai diperoleh perangkat yang ideal dari ukuran derajat IO.

Jika terdapat kekonsistenan antara hasil penilaian ahli dan praktisi (intended-perseived) dengan hasil pengamatan keterlaksanaan perangkat dilapangan oleh pengamat (intended-operation) yaitu sama-sama memberikan hasil penilaian yang tinggi, maka perangkat memenuhi kriteria kepraktisan.

\section{Keefektifan}

Menurut Hasratuddin (Hasratuddin, 2015) kriteria penentuan pencapaian keefektifan perangkat pembelajaran berdasarkan pada empat indikator keefektifan pembelajaran yaitu : (1) Pencapaian ketuntasan belajar apabila $80 \%$ siswa yang mengikuti tes kemampuan pemecahan masalah matematis telah memperoleh nilai 75; (2) pencapaian ketuntasan tujuan pembelajaran (minimal $75 \%$ tujuan pembelajaran yang dirumuskan dapat dicapai oleh minimal 65\% siswa); (3) waktu yang digunakan dalam pembelajaran efisien atau tidak melebihi pembelajaran biasa; (4) respon siswa terhadap pembelajaran.

Data yang diperoleh dari hasil tes awal dan tes akhir dianalisis untuk mengetahui peningkatan kemampuan komunikasi matematis siswa. Skor yang diperoleh dari hasil tes siswa sebelum dan setelah menggunakan perangkat pembelajaran yang telah dikembangkan dianalisis dengan cara membandingkan skor siswa yang diperoleh dari hasil tes siswa sebelum dan setelah diberi perlakuan. Besarnya peningkatan sebelum dan sesudah pembelajaran dihitung dengan rumus $\mathrm{N}$-gain dari Hake (Hake, 1999) sebagai berikut: 


$$
\text { Indeks Gain Ternormalisasi }=\frac{\text { Skor postest-Skor Pretest }}{\text { Skor Ideal-Pretest }}(\text { Hake, 1999) }
$$

Dengan kriteria indeks gain seperti pada Tabel 4. berikut:

Tabel 4. Kriteria Skor Gain Ternormalisasi

\begin{tabular}{|c|c|}
\hline Skor Gain & Interpretasi \\
\hline \hline$g>0,7$ & Tinggi \\
\hline $0,3<g \leq 0,7$ & Sedang \\
\hline$g \leq 0,3$ & Rendah \\
\hline
\end{tabular}

Sumber: (Hake, 1999)

\section{HASIL DAN DISKUSI}

Hasil penelitian disajikan dalam bentuk grafik, tabel, atau deskriptif. Analisis dan interpretasi hasil ini diperlukan sebelum dibahas.

\section{Hasil Validitas Model Pembelajaran Interaktif Berbasis Think Pair Share}

Berdasarkan hasil validasi model pembelajaran interaktif think pair share yang dikembangkan diperoleh bahwa model pembelajaran interaktif dinyatakan valid atau memiliki derajat validitas yang baik. Kemudian model pembelajaran interaktif yang dikembangkan juga dikatakan layak berdasarkan semua aspek kevalidan model pembelajaran interaktif. Selanjutnya hasil validasi terhadap rencana pelaksanaan pembelajaran (RPP), Buku Siswa (BS), Lembar Kerja Peserta Didik (LKPD) dan tes kemampuan komunikasi matematis juga valid atau memiliki derajat validitas yang baik. Hal ini menunjukkan bahwa model pembelajaran interaktif think pair share yang dikembangkan beserta RPP, Buku Siswa (BS), LKPD dan tes kemampuan komunikasi matematis telah memenuhi kriteria kevalidan.

Hasil validasi yang dilakukan oleh ahli model pembelajaran juga ahli imateri pembelajaranimatematika secara umum berarti bahwa model pembelajaran interaktif think pair share yang dikembangkan secara umum dapat memenuhi tuntutan kebutuhan pembelajaran untuk materi bangun datar persegi dan persegi panjang. Sehingga dapat disimpulkan bahwa model pembelajaran interaktif think pair share yang dikembangkan dalam penelitian ini sudah memenuhi kriteria validitas.

\section{Hasil Kepraktisan Model Pembelajaran Interaktif Berbasis Think Pair Share}

Berdasarkan hasil penilaian dari para ahli (validator), semua validator menyatakan bahwa media pembelajaran buku digital interaktif yang dikembangkan layak digunakan dengan sedikit revisi. Hal ini didukung oleh penelitian Annisa, Putra, dan Dharmono (Annisa et al., 2020) yang menyatakan bahwa kepraktisan media pembelajaran penting untuk diketahui karena salah satu syarat media pembelajaran adalah mudah untuk digunakan oleh pengguna.

Kemudian, melalui lembar observasi keterlaksanaan pembelajaran dengan menggunakan model pembelajaran interaktif berbasis think pair share yang dikembangkan yang diberikan kepada seorang pengamat di setiap pertemuan uji coba I dan II diperoleh hasil bahwa skor observasi keterlaksanaan pembelajaran belum memenuhi kriteria kepraktisan pada uji coba I yaitu dengan skor 
2,93 pada pertemuan I, skor 3,13 pada pertemuan II, dan rata- rata 3,03 (kategori "Sedang"). Sedangkan pada uji coba II diperoleh skor 3,87 pada pertemuan I, 4,00 pada pertemuan II, dan 4,27 pada pertemuan III. Rata-rata hasil observasi keterlaksanaan pembelajaran pada uji coba II adalah 4,04 dengan kategori "Tinggi". Hal ini didukung oleh pendapat Akker (Akker, 2007) yang menyatakan bahwa kriteria kepraktisan media pembelajaran dikatakan praktis apabaila hasil pengamatan media pembelajaran di kelas termasuk dalam kategori baik atau sangat baik. Dalam penelitian Marselina \& Muhtadi (Marselina \& Muhtadi, 2019) bahwa media pembelajaran buku digital mudah digunakan dan efektif untuk meningkatkan hasil belajar siswa. Maka dari itu, dapat disimpulkan bahwa buku digital interaktif yang dikembangkan sudah memenuhi indikator kepraktisan.

\section{Hasil Analisis Model Pembelajaran Interaktif Berbasis Think Pair Share}

Produk dari penelitian ini berupa buku digital siswa berbasis model pembelajaran interaktif menggunakan model Think Pair Share pada materi segi empat untuk siswa SMP kelas VII. Desain penelitian ini dilakukan melalui 5 tahap utama, yaitu analysis, design, development, implementation, dan evaluatio.

Uji coba I dilakukan dikelas VII-1 dengan jumlah siswa 15 orang. Uji coba I terdiri dari 2 kali pertemuan sesuai dengan rencana pelaksanaan pembelajaran (RPP) yang telah disusun. Pada tahap uji coba ini, peneliti bertindak sebagai guru yang mengajar. Pembelajaran dilakukan secara individual karena proses belajar mengajar harus tetap mengikuti program social and physical distancing untuk menghindari penyebaran virus Covid-19. Adapun kegiatan yang dilakukan dapat dilihat dalam Rencana Pelaksanaan Pembelajaran (RPP) pada lampiran.

Dari analisis hasil uji coba I, peneliti menemukan beberapa kelemahan yang harus diperbaiki agar penelitian ini dapat menghasilkan buku digital siswa dan perangkat yang memenuhi seluruh kriteria valid, praktis, dan efektif. Setelah revisi selesai dilakukan, maka uji coba II menggunakan buku digital siswa (draft II) dan perangkatnya dilaksanakan di kelas VII MTS Amin Darussalam dengan jumlah siswa 15 orang. Uji coba II ini dilakukan untuk mengukur apakah buku digital siswa dan perangkatnya memenuhi seluruh kriteria valid, praktis, dan efektif yang telah ditetapkan. Secara keseluruhan, hasil analisis data uji coba II menunjukkan bahwa media pembelajaran yang dikembangkan telah memenuhi seluruh kriteria valid, praktis, dan efektif yang ditetapkan. Penjelasan lebih lengkap dapat dilihat pada bagian deskripsi kevalidan, kepraktisan, dan keefektifan buku digital siswa dan perangkatnya.

\section{Peningkatan Kemampuan Komunikasi Matematis Siswa}

Jika dikategorikan berdasarkan tingkat penguasaan siswa, maka tingkat penguasaan kemampuan komunikasi matematis siswa pada hasil posttest uji coba I dapat dilihat pada Tabel 4. 
Tabel 4. Tingkat Penguasaan Kemampuan Komunikasi Matematis Hasil Posttest Uji Coba I

\begin{tabular}{|c|c|c|c|l|}
\hline \multirow{2}{*}{ No } & \multirow{2}{*}{ Interval Nilai } & \multicolumn{3}{|c|}{$\begin{array}{c}\text { Kemampuan Penalaran } \\
\text { Matematis }\end{array}$} \\
\cline { 3 - 4 } & & Kumlah Siswa & Persentase & \\
\hline 1 & $0 \leq \mathrm{KKM}<55$ & 0 & $0 \%$ & Kurang \\
\hline 2 & $56 \leq \mathrm{KKM}<75$ & 8 & $53,4 \%$ & Cukup \\
\hline 3 & $76 \leq \mathrm{KKM}<85$ & 6 & $40 \%$ & Baik \\
\hline 4 & $86 \leq \mathrm{KKM}<100$ & 1 & $6,6 \%$ & Sangat Baik \\
\hline
\end{tabular}

Berdasarkan Tabel 4. diperoleh hasil posttest Kemampuan Komunikasi Matematis Siswa yaitu, tidak ada siswa yang memperoleh kategori sangat kurang (0\%), yang memperoleh kategori kurang sebanyak 8 siswa (53,4\%), yang memperoleh kategori cukup sebanyak 6 siswa (40\%), yang memperoleh kategori baik sebanyak 1 siswa $(6,6 \%)$. Untuk lebih jelasnya dapat dilihat pada diagram yang disajikan pada Gambar 2. berikut.

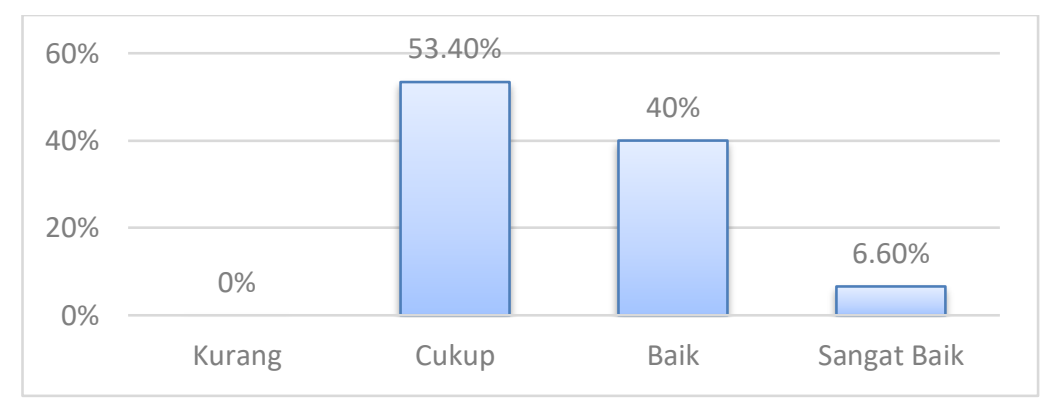

Gambar 2. Tingkat Kemampuan Komunikasi Matematis Hasil Posttest Uji Coba I

Jika dikategorikan berdasarkan tingkat penguasaan siswa, maka tingkat penguasaan kemampuan komunikasi matematis siswa pada hasil posttest uji coba II dapat dilihat pada Tabel 5:

Tabel 5. Tingkat Penguasaan Kemampuan Komunikasi Matematis Hasil Posttest Uji Coba II

\begin{tabular}{|c|c|c|c|l|}
\hline \multirow{2}{*}{ No } & \multirow{2}{*}{ Interval Nilai } & \multicolumn{2}{|c|}{$\begin{array}{c}\text { Kemampuan Penalaran } \\
\text { Matematis }\end{array}$} & \multirow{2}{*}{ Keterangan } \\
\cline { 3 - 4 } & & Jumlah Siswa & Persentase & \\
\hline 1 & $0 \leq \mathrm{KKM}<55$ & 0 & $0 \%$ & Kurang \\
\hline 2 & $56 \leq \mathrm{KKM}<75$ & 5 & $33,3 \%$ & Cukup \\
\hline 3 & $76 \leq \mathrm{KKM}<85$ & 8 & $53,33 \%$ & Baik \\
\hline 4 & $86 \leq \mathrm{KKM}<100$ & 2 & $13,4 \%$ & Sangat Baik \\
\hline
\end{tabular}

Berdasarkan Tabel 5. diperoleh hasil posttest Kemampuan Komunikasi Matematis Siswa yaitu, tidak ada siswa yang memperoleh kategori sangat kurang (0\%), yang memperoleh kategori cukup sebanyak 5 siswa (33,33\%), yang memperoleh kategori baik sebanyak 8 siswa (53,33\%), yang memperoleh kategori sangat baik sebanyak 2 siswa $(13,34 \%)$. Untuk lebih jelasnya dapat dilihat pada diagram yang disajikan pada Gambar 3: 


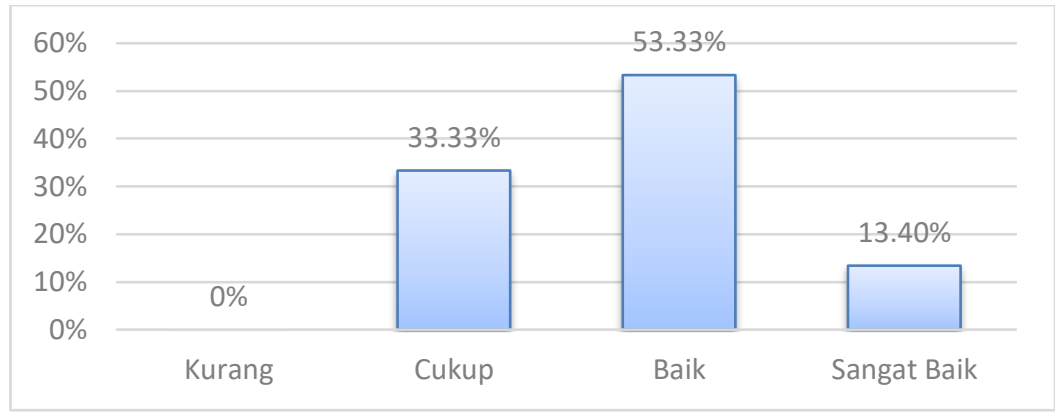

Gambar 3. Tingkat Kemampuan Komunikasi Matematis Hasil Posttest Uji Coba II

Berdasarkan hasil analisis tes kemampuan komunikasi matematis siswa pada uji coba I dan uji coba II menunjukkan bahwa terdapat peningkatan kemampuan komunikasi matematis siswa. Berdasarkan rata-rata gain ternormalisasi, diperoleh bahwa pada uji coba I terjadi peningkatan kemampuan komunikasi matematis siswa dengan kriteria "sedang" dengan skor $0,34(0,3<g \leq 0,7)$ dan pada uji coba II terjadi peningkatan nilai dengan kriteria "sedang" dengan skor $0,41(0,3<N$-Gain $\leq 0,7)$. Sehingga dapat disimpulkan bahwa model pembelajaran interakitf berbasis think pair share yang dikembangkan ini dapat meningkatkan kemampuan komunikasi matematis siswa.

\section{KESIMPULAN}

1. Model pembelajaran interaktif think pair share yang dikembangkan diperoleh bahwa model pembelajaran interaktif dinyatakan valid, praktis, dan efektif.

2. Berdasarkan indeks gain ternormalisasi, diperoleh bahwa pada uji coba I terjadi peningkatan kemampuan komunikasi matematis siswa dengan kriteria "sedang" dengan skor $0,34(0,3<N$ Gain $\leq$ 0,7) dan pada uji coba II terjadi peningkatan nilai dengan kriteria "sedang" dengan skor $0,41(0,3<N$-Gain $\leq 0,7)$. Sehingga dapat disimpulkan bahwa model pembelajaran interaktif berbasis think pair share yang dikembangkan ini dapat meningkatkan kemampuan komunikasi matematis siswa.

\section{UCAPAN TERIMA KASIH}

Terima kasih saya ucapkan kepada dosen pembimbing Bapak Dr. Mulyono, M.Si dan Bapak Prof. Dr. Edi Syahputra, M.Pd., dan. Terimakasih juga saya ucapkan untuk semua pihak yang membantu dalam menyelesaikan penelitian ini

\section{REFERENSI}

'Ainin, Q., Mulyono, Edi, S., \& Elmanani, S. (2020). Pengembangan Model Pembelajaran Kooperatif Think Talk Write Berbasis Adobe Flash Untuk Meningkatkan Kemampuan Berpikir Kritis. Paradikma Jurnal Pendidikan Matematika, 11(2), 1-10.

Abidin, Z. (2016). Pengembangan Model Pembelajaran Matematika Berbasis Portofolio (Pmbp) Pada Siswa Sekolah Menengah Pertama. JPM: Jurnal Pendidikan Matematika, 2(1), 79. 
https://doi.org/10.33474/jpm.v2i1.209

Aminudin, M. (2017). Efektivitas Model Pembelajaran Tps (Think Pair Share) Dan Nested Berbantuan Kartu Soal Untuk Meningkatkan Hasil Belajar Materi Statistika Siswa Sma N 2 Pekalongan. Aksioma, 6(2), 28. https://doi.org/10.26877/aks.v6i2.1400

Hake, R. (1999). Analyzing Change/Gain Scores. Dept. of Physcis, Indiana University. Hasratuddin. (2015). Mengapa Harus Belajar Matematika? Perdana Publishing.

Hobri. (2010). Metodologi Penelitian Pengembangan [Aplikasi Pada penelitian Pendidikan Matematika]. Pena Salsabila.

Iswari, A. P. (2018). Perbandingan Hasil Belajar Antara Model Pembelajaran Konvensional Dengan Model Pembelajaran Kooperatif Tipe Team Accelerated Instruction (Tai) Pada Mata Pelajaran Mekanika Teknik Kelas X TGB di SMKN 2 Surakarta. Surakarta: Universitas Sebelas Maret.

Jurotun. (2015). Meningkatkan Komunikasi Matematis Peserta Didik melalui "Disco LeMPer “ berbantuan Software Geogebra. Kreano Jurnal Matematika Kreatif - Inovatif, 6(1), 1-6.

Mahmuzah, R., Ikhsan, M., \& Yusrizal. (2014). Peningkatan Kemampuan Berpikir Kritis Dan Disposisi Matematis Siswa Smp Dengan Menggunakan Pendekatan Problem Posing. Didaktik Matematika, 1(2), 43-53. https://doi.org/10.24815/jdm.v1i2.2060

Perwitosari, N., Asnawati, R., \& Bharata, H. (2018). Pengaruh Pembelajaran Think Pair Share Terhadap Kemampuan Komunikasi Matematis Siswa. 6, 535-546.

Rahayu \& Wirevenska. (2019). Pengaruh Model Pembelajara Kooperatif Tipe Think Pair Share terhadap Kemampuan Komunikasi Matematis Siswa Kelas VIII SMP Negeri 4 Binjai TP 2017/2018. Jurnal Serunai Matematika, Vol. 11, N.

Rahmawati, U., \& Suryanto, S. (2014). Pengembangan Model Pembelajaran Matematika Berbasis Masalah Untuk Siswa Smp. Jurnal Riset Pendidikan Matematika, $1(1), 88$. https://doi.org/10.21831/jrpm.v1i1.2667

Susanto, J. (2012). Pengembangan Perangkat Pembelajaran Berbasis Lesson Study Dengan Kooperatif Tipe Numbered Heads Together Untuk Meningkatkan Aktivitas Dan Hasil Belajar Ipa Di Sd. Journal of Primary Education, 1(2). https://doi.org/10.15294/jpe.v1i2.785

Syahputra, E., \& Surya, E. (2015). Pengembangan Model Pembelajaran Berbasis Pemecahan Masalah Untuk Mengkonstruksi Berpikir Tingkat Tinggi Dalam Pembelajaran Matematika di SMA/MA. Prosiding Semirata 2015 Bidang MIPA BKS-PTN Barat, 125-137.

Tampubolon, S. W., \& Syahputra, E. (2017). Perbedaan Peningkatan Kemampuan Berpikir Kreatif Matematis Siswa Menggunakan Model Pembelajaran Kooperatif Tipe Berkirim Salam dan Soal dengan Think Pair Share di SMP Swasta Imelda Medan. Inspiratif: Jurnal Pendidikan Matematika, 3(1). https://doi.org/10.24114/jpmi.v3i1.8797

Wibowo, P. A., Budiyono, \& Subanti, S. (2014). Pengembangan Model Pembelajaran Think Pair Share (TPS) Berbasis Assesment For Learning (AFL) Melalui Teman Sejawat Untuk Pembelajaran Matematika Pada Pokok Bahasan Sistem Persamaan Linear Dua Variabel Di 
Pengembangan Model Pembelajaran Interaktif Berbasis Think Pair Share Untuk Meningkatkan Kemampuan Komunikasi Matematis Siswa, Siti Asfiranna Sari Dalimunthe, Mulyono, Edi Syahputra

SMP/MTs Se-Kabupaten Magelang Tahun Pelajaran 2013/. Jurnal Elektronik Pembelajaran Matematika, 2(7), 694.

Widayati, I. (2012). Faktor Faktor yang mempengaruhi Literasi Finensial Mahasiswa Fakultas Ekonomi dan Bisnis Universitas Brawijaya. Jurnal Akutansi Dan Pendidikan. IKIP PGRI Madiun. 